\title{
Idea o tema cartográfico y fuentes de información: relaciones, restricciones y potencialidades
}

\author{
Ramirez, Mirta Liliana
}

Publicado en formato digital: Ramirez, Mirta Liliana. Idea o tema cartográfico y fuentes de información: relaciones, restricciones y potencialidades. Resúmenes. Revista Geográfica Digital. IGUNNE. Facultad de Humanidades. UNNE. Año 7. № 13. Enero - Junio 2010. Resistencia, Chaco. En: http://hum.unne.edu.ar/revistas/geoweb/default.htp 
Tema 1. 1: Definición y tipos de Cartografía Temática

Tema 1.2: Generalidades del proceso de elaboración de

Cartografía Temática

Tema L.3: La idea cartográfica o tema a abordar

PROGRAMA DE LAASIGNAJUURA Temática

Parte I: Cartografía

Parte II:

Sistemas de Información Geográfica -SIG-

Parte III: Conexión entre la Cartografía, los SIG y la Teledetección
Tema l.4: Fuentes de información para la cartografía temática

Tema 1.5: La construcción o diseño intelectual de la representación

Tema l.6: La ejecución de la representación, sintaxis o elaboración cartográfica propiamente dicha

Tema l.7: Los tipos de representaciones temáticas

Tema 1.8: La lectura, análisis e interpretación cartográfica

Publicado en formato digital: Ramirez, Mirta Liliana. Idea o tema cartográfico y fuentes de información: relaciones, restricciones y potencialidades. Resúmenes. Revista Geoqráfica Diqital. IGUNNE. Facultad de Humanidades. UNNE. Año 7. № 13. Enero - Junio 2010. Resistencia, Chaco. En: http://hum.unne.edu.ar/revistas/qeoweb/default.hth 


\section{DEFINICION}

prosesou conj unto de fases sucesivas de un fenómeno natural o de una operación artificial.

freseso de eláéresjón d'e Cartegrefifía

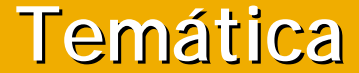

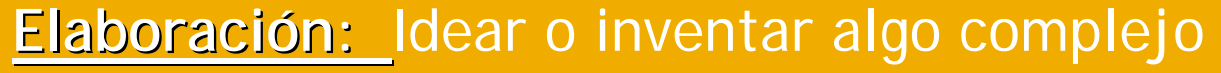

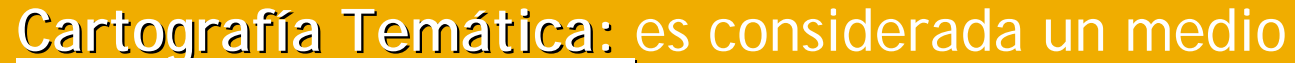
de expresión gráfica, cercano al hombre, que utiliza como soporte el fondo topográfico generado por la cartografía básica y con la ayuda de leyendas y convenciones, expresa un mensaj e de la ciencia temática para la cual ha sido diseñada (IGAC, 1993). 


\section{DEFINICION}

Rseceso de

ejaborasjós d’e

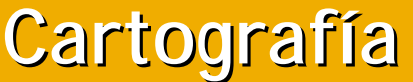

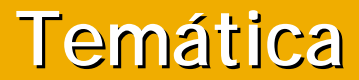

La elaboración de cartografía temática es concebida como un proceso comunicativo que involucra todos los elementos que conforman la comunicación: el emisor, la simbología, la transmisión, los signos recibidos y, por último, el receptor

\section{Contexto}

Instituciones educativas-organizaciones gubernamentales y ONG's Emisor

Mensaje

\section{Receptor}

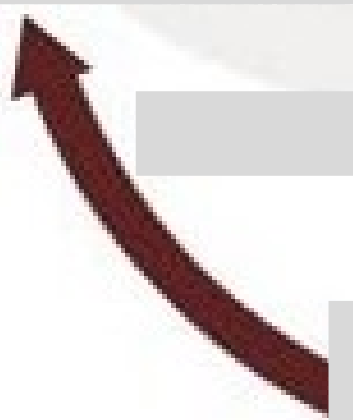

Código

Semiología gráfica

Canal

Representaciones

cartográficas

Publicado en formato digital: Ramirez, Mirta Liliana. Idea o tema cartográfico y fuentes de información: relaciones, restricciones y potencialidades. Resúmenes. Revista Geográfica Digital. IGUNNE. Facultad de Humanidades. UNNE. Año 7. № 13. Enero - Junio 2010. Resistencia, Chaco. En: http://hum.unne.edu.ar/revistas/geoweb/default.htı̊ 
$\checkmark$ Tipos de lectura: científica y cultural.

$\checkmark$ Tener presente el nivel mental y el nivel de lectura cartográfica.

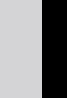

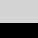

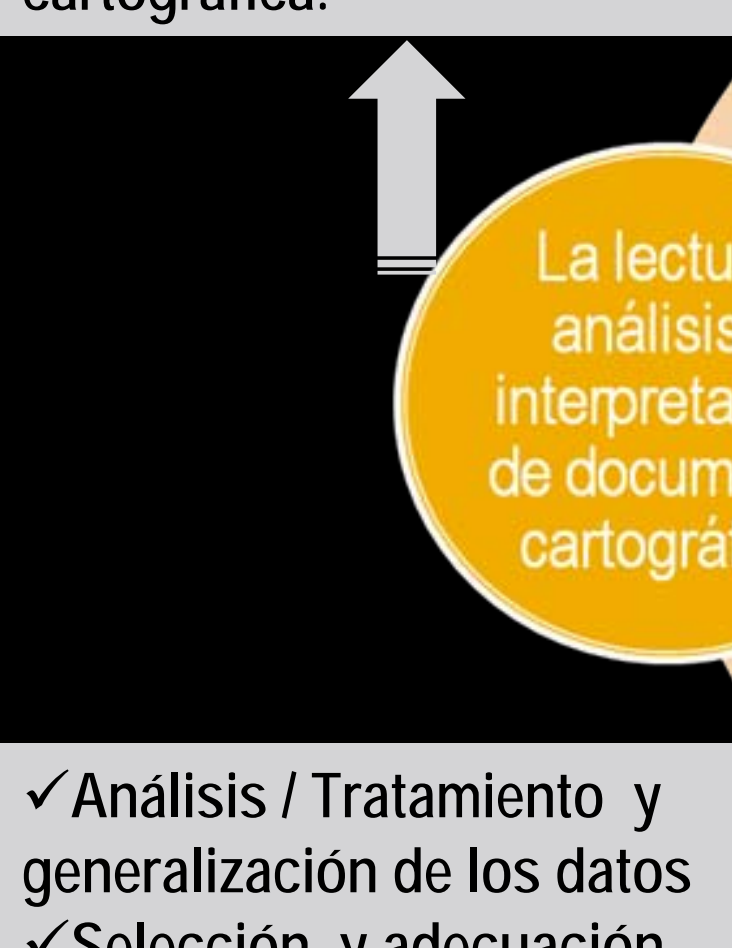
$\checkmark$ Selección y adecuación de variables visuales $\checkmark$ Diseño y composición $\checkmark$ Impresión y reproducción $\checkmark$ Especificación de los objetivos

$\checkmark$ Definición de la escala de trabajo y esbozo del mapa base

$\checkmark$ Fuentes de información 


\section{DATOS}

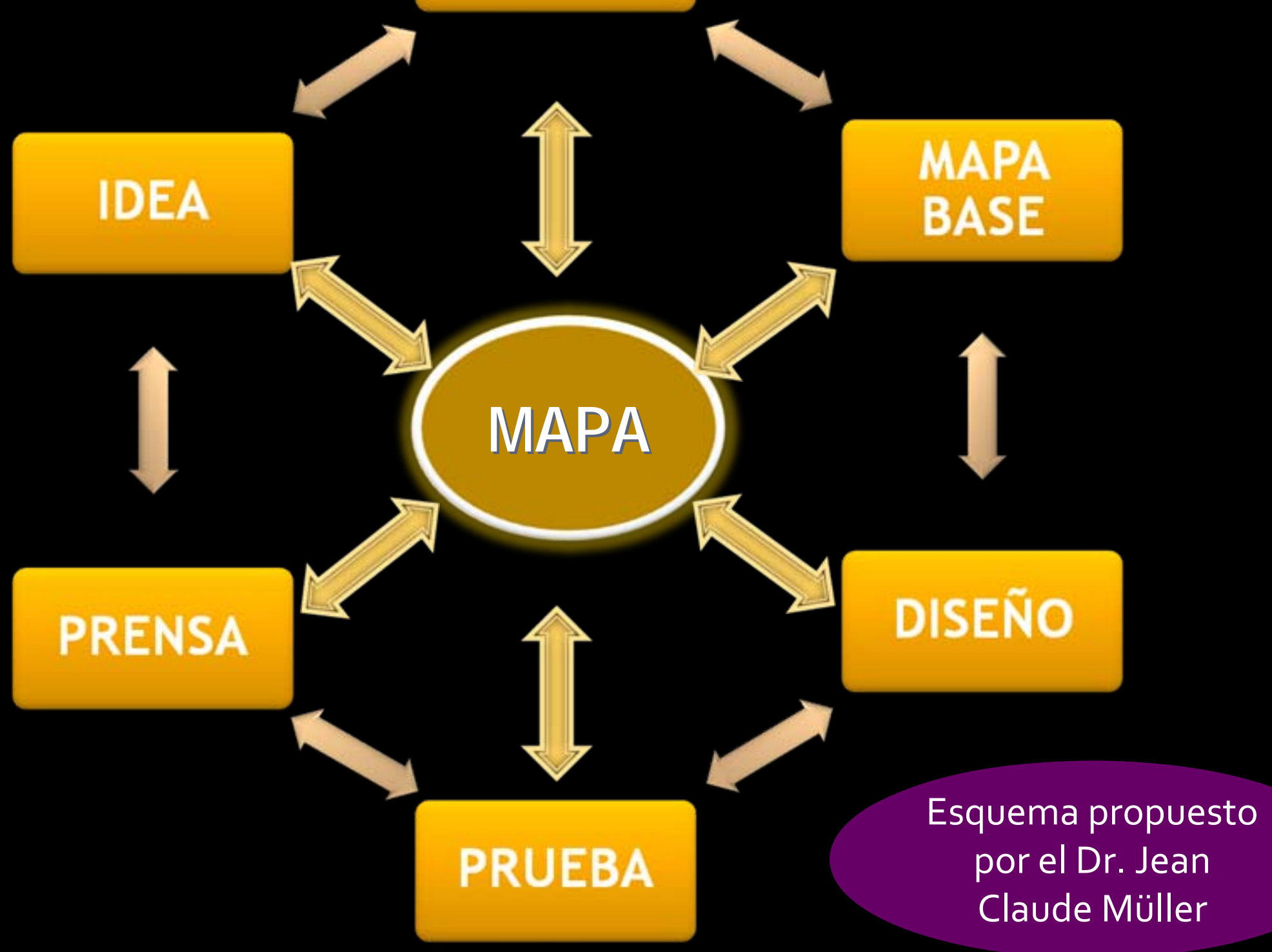

Publicado en formato digital: Ramirez, Mirta Liliana. Idea o tema cartográfico y fuentes de información: relaciones, restricciones y potencialidades. Resúmenes. Revista Geográfica Digital. IGUNNE. Facultad de Humanidades. UNNE. Año 7. № 13. Enero - Junio 2010. Resistencia, Chaco. En: http://hum.unne.edu.ar/revistas/geoweb/default.htø 
$\checkmark$ Tipos de lectura: científica y cultural.

$\checkmark$ Tener presente el nivel mental y el nivel de lectura cartográfica.

\section{Enfoque de comunicación}

\section{Enfoques} tecnológico, artístico y de presentación

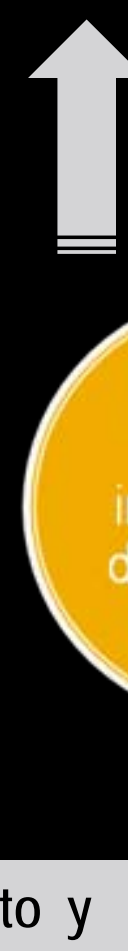

$\checkmark$ Análisis / Tratamiento y generalización de los datos $\checkmark$ Selección y adecuación de variables visuales $\checkmark$ Diseño y composición $\checkmark$ Impresión y reproducción $\checkmark$ Especificación de los objetivos

$\checkmark$ Definición de la escala de trabajo y esbozo del mapa base

$\checkmark$ Fuentes de información 


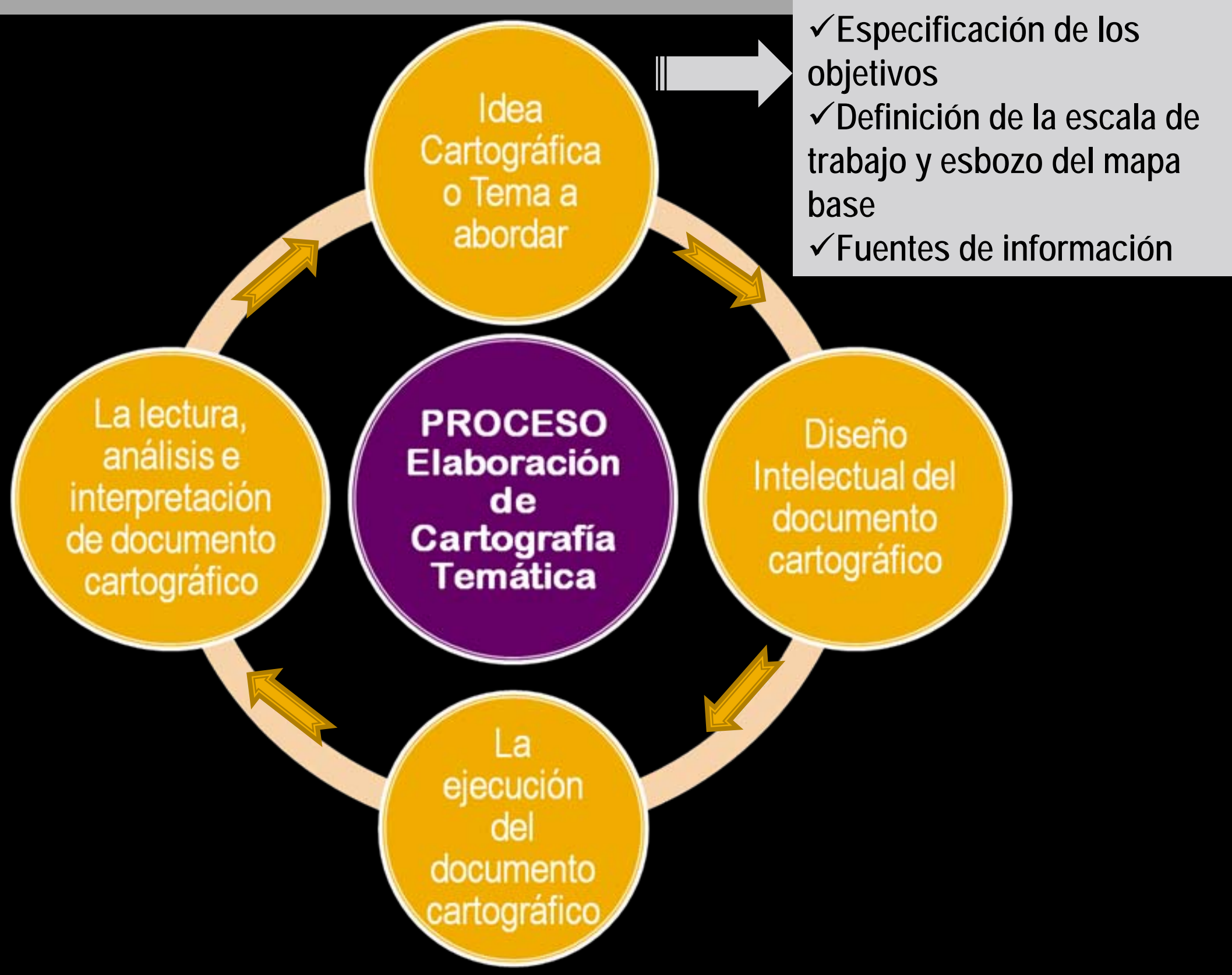

Publicado en formato digital: Ramirez, Mirta Liliana. Idea o tema cartográfico y fuentes de información: relaciones, restricciones y potencialidades. Resúmenes. Revista Geográfica Digital. IGUNNE. Facultad de Humanidades. UNNE. Año 7. № 13. Enero - Junio 2010. Resistencia, Chaco. En: http://hum.unne.edu.ar/revistas/geoweb/default.htg̊ 


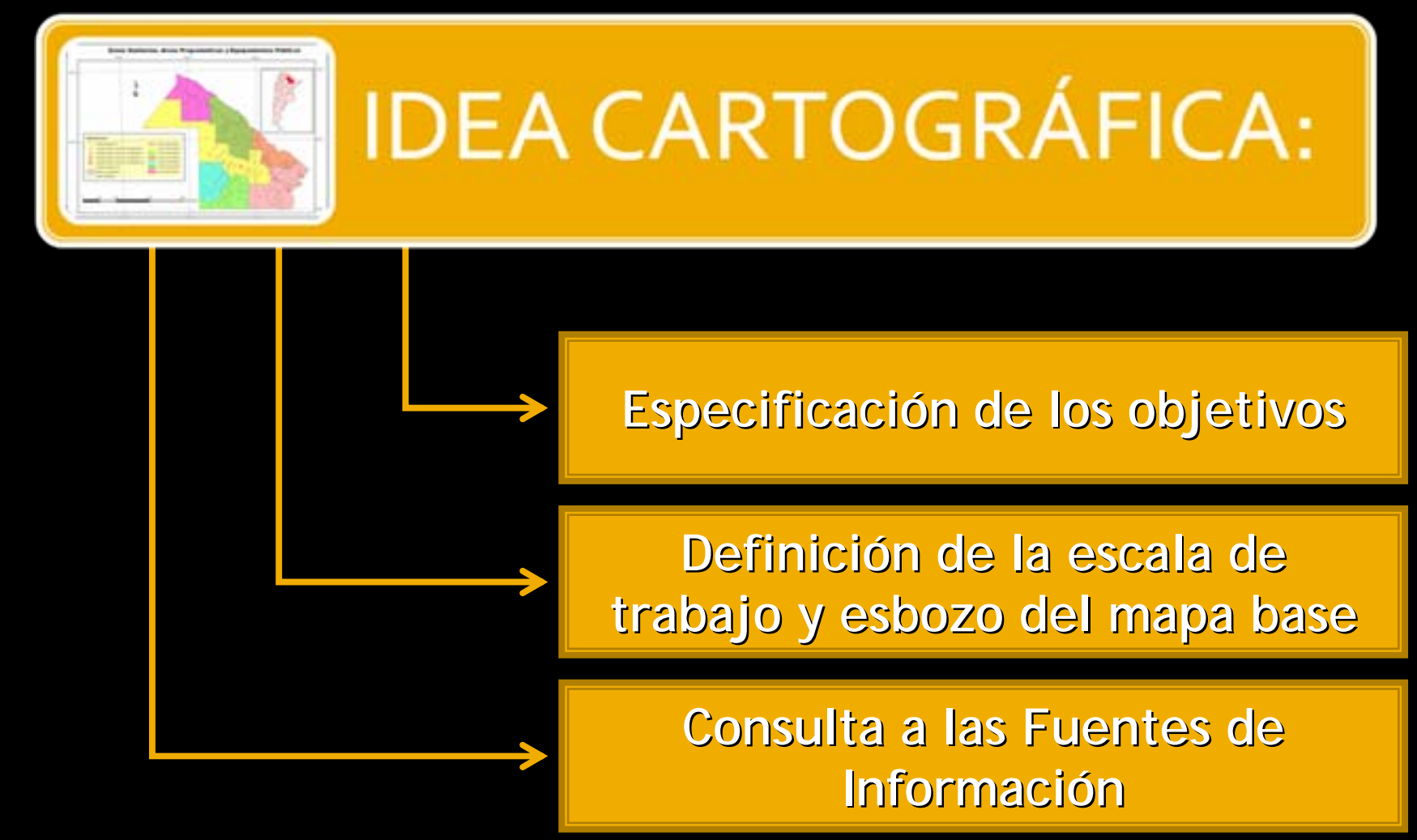

Publicado en formato digital: Ramirez, Mirta Liliana. Idea o tema cartográfico y fuentes de información: relaciones, restricciones y potencialidades. Resúmenes. Revista Geográfica Digital. IGUNNE. Facultad de Humanidades. UNNE. Año 7. № 13. Enero - Junio 2010. Resistencia, Chaco. En: http://hum.unne.edu.ar/revistas/geoweb/default. $\mathbb{1}_{10}$ 


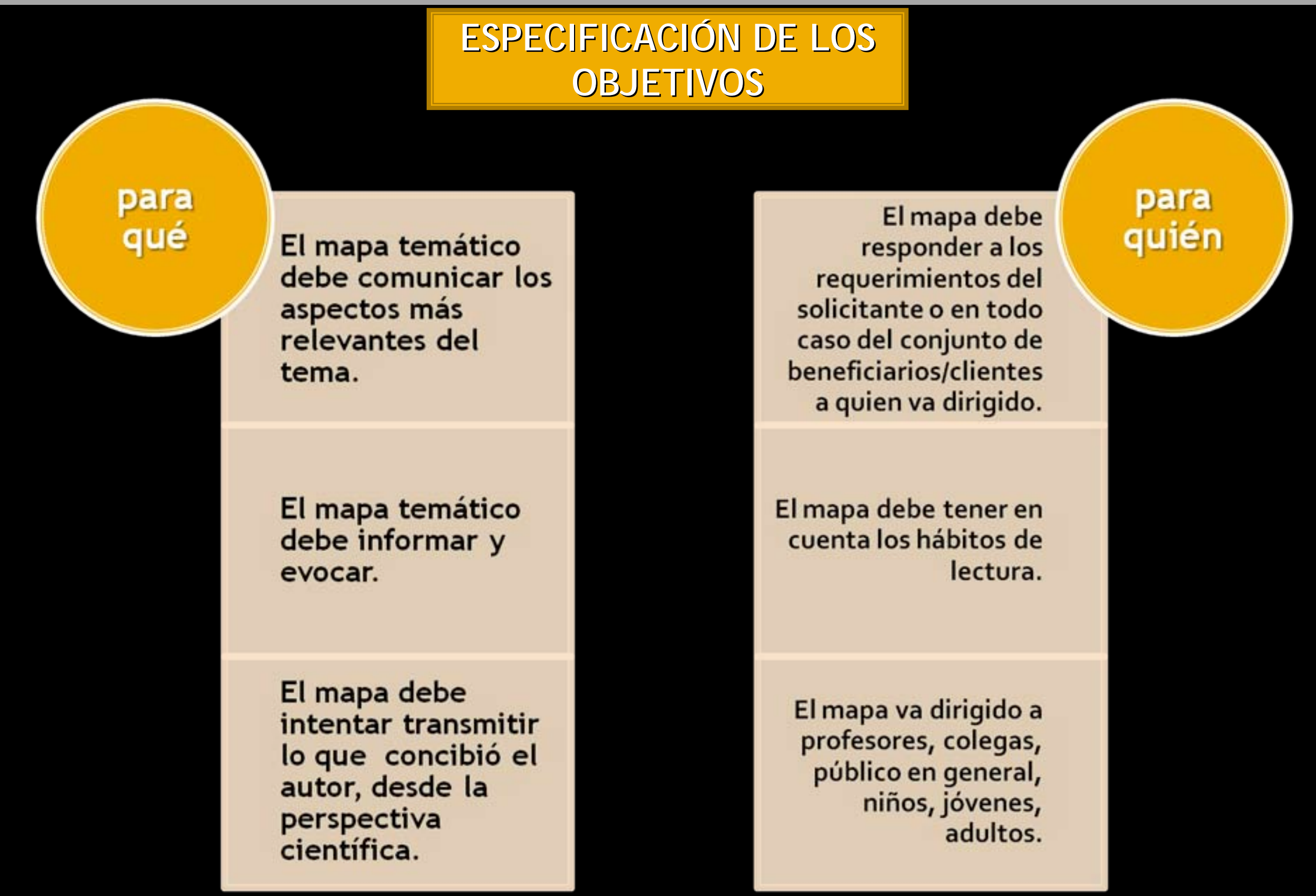

Publicado en formato digital: Ramirez, Mirta Liliana. Idea o tema cartográfico y fuentes de información: relaciones, restricciones y potencialidades. Resúmenes. Revista Geográfica Digital. IGUNNE. Facultad de Humanidades. UNNE. Año 7. № 13. Enero - Junio 2010. Resistencia, Chaco. En: http://hum.unne.edu.ar/revistas/geoweb/default.hł† 


\section{ESFECJF」CAJCJÓN DE LOS OEJ $E\lceil\rfloor$ VOS}

fuentes de información

\section{Cartográficas}

Estadísticas

Bibliográficas

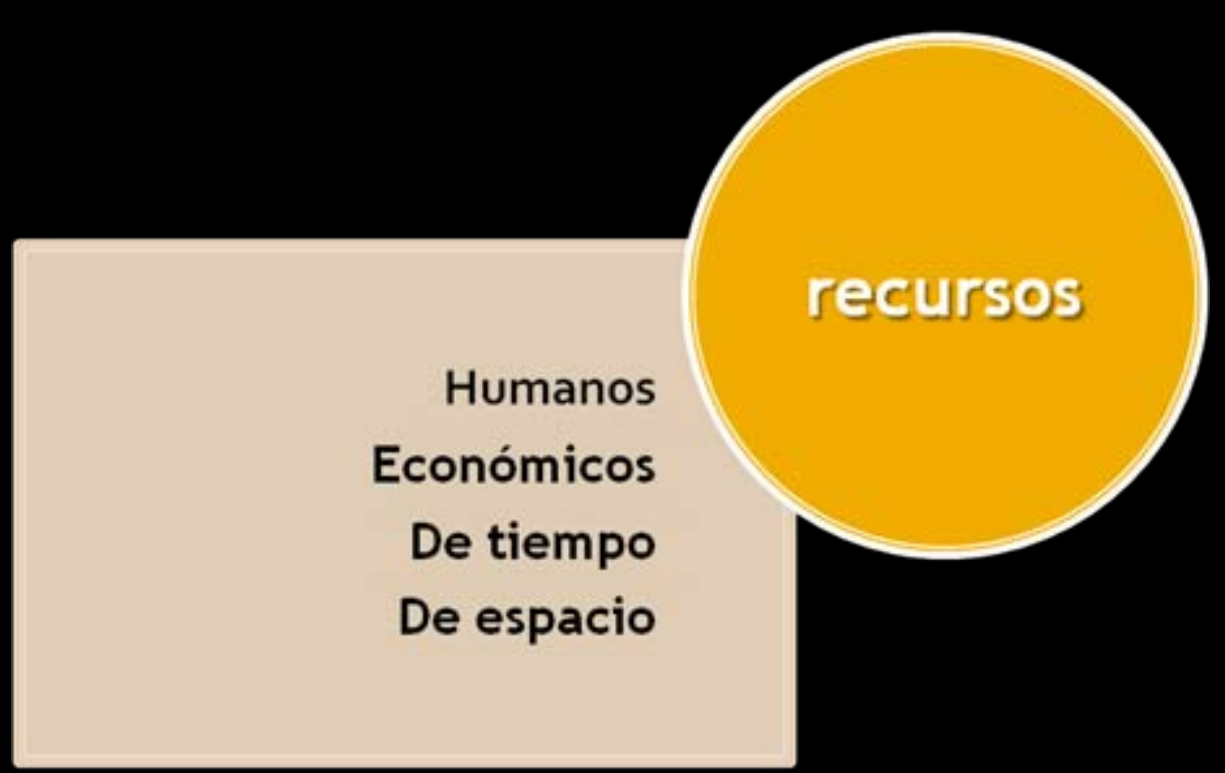




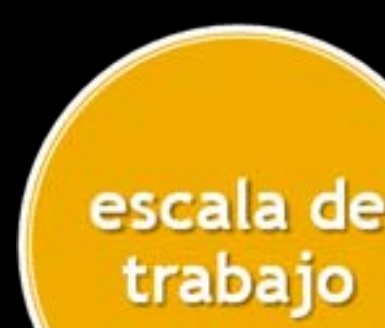

DËJ」J」ÓN DE LA ESCALLA DE

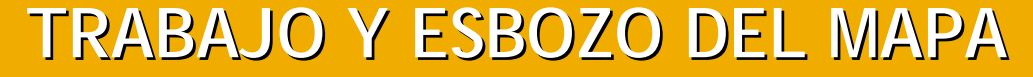
르스를

Esta en directa relación con las unidades espaciales de menor y mayor extensión. MUC

Existe una relación muy entre escala, detalle y generalización.

Difiere según se trate de un documento de inventario o de síntesis.
Debe estar poco marcado, se debe distinguir la información temática.

Los componentes del mapa base dependen de la naturaleza del tema a representar, del propósito y de la escala

Es preciso logar el equilibrio en la distribución de los componentes del mapa base. mapa base 


\section{CONEULJA LA LAS HUENJES DE INFCRUACION}

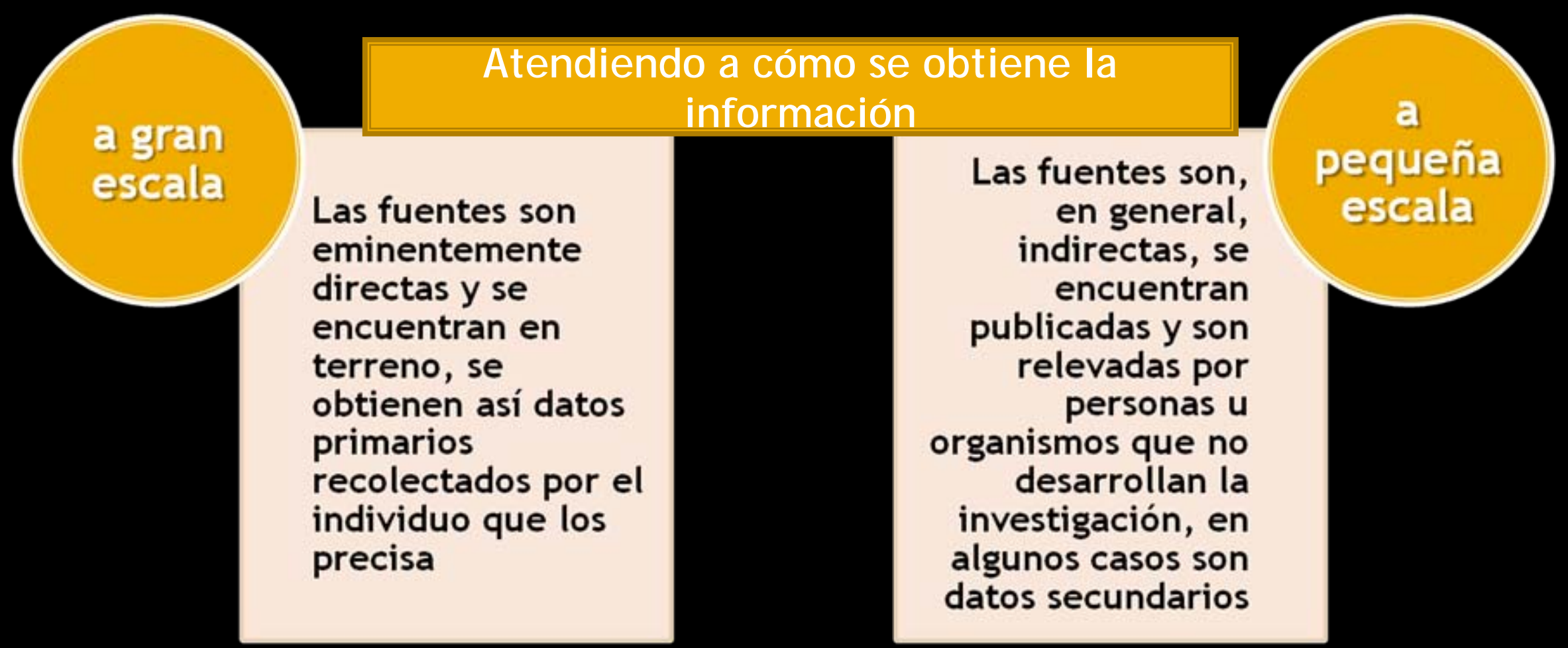

\section{Atendiendo a la información que aportan}

Cartográficas, bibliográficas, estadísticas, fotográficas, hemerográficas, iconográficas 


\section{CONEULJA LAS LUENJES DE

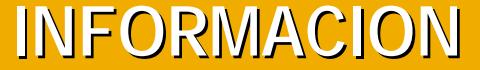

\section{a gran escala y a pequeña escala}

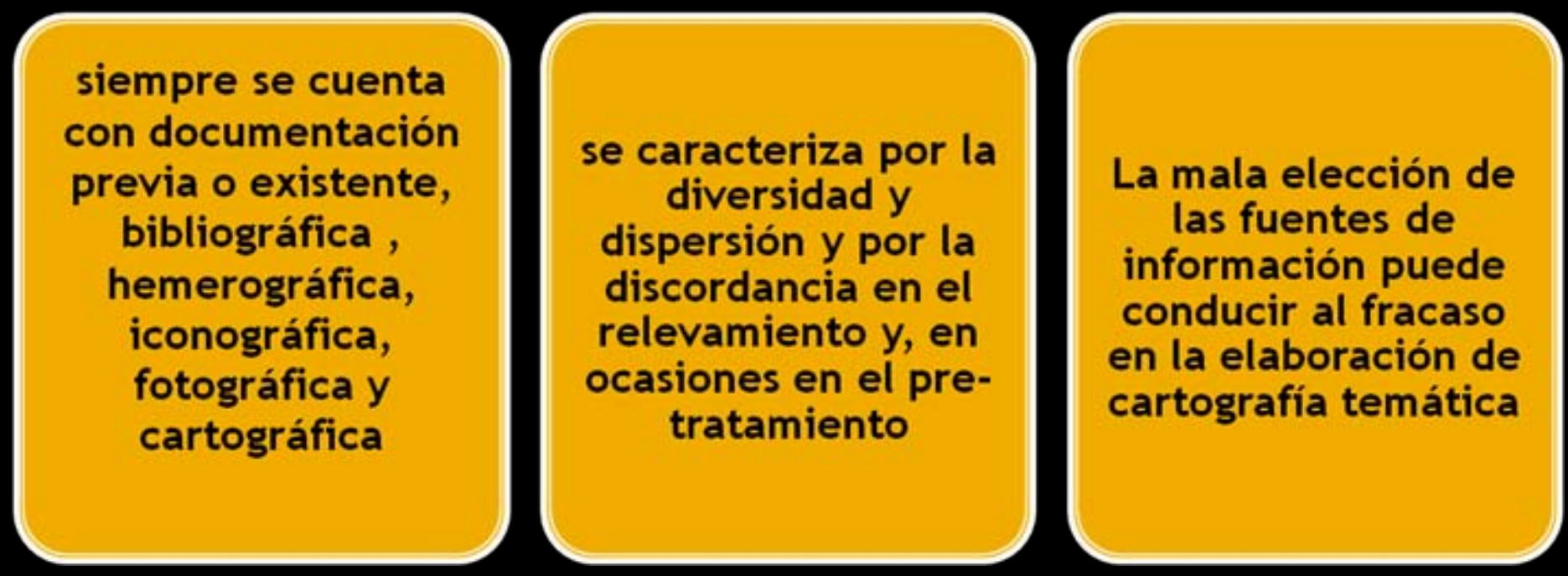




\section{FUENTES DE INFORMACION}

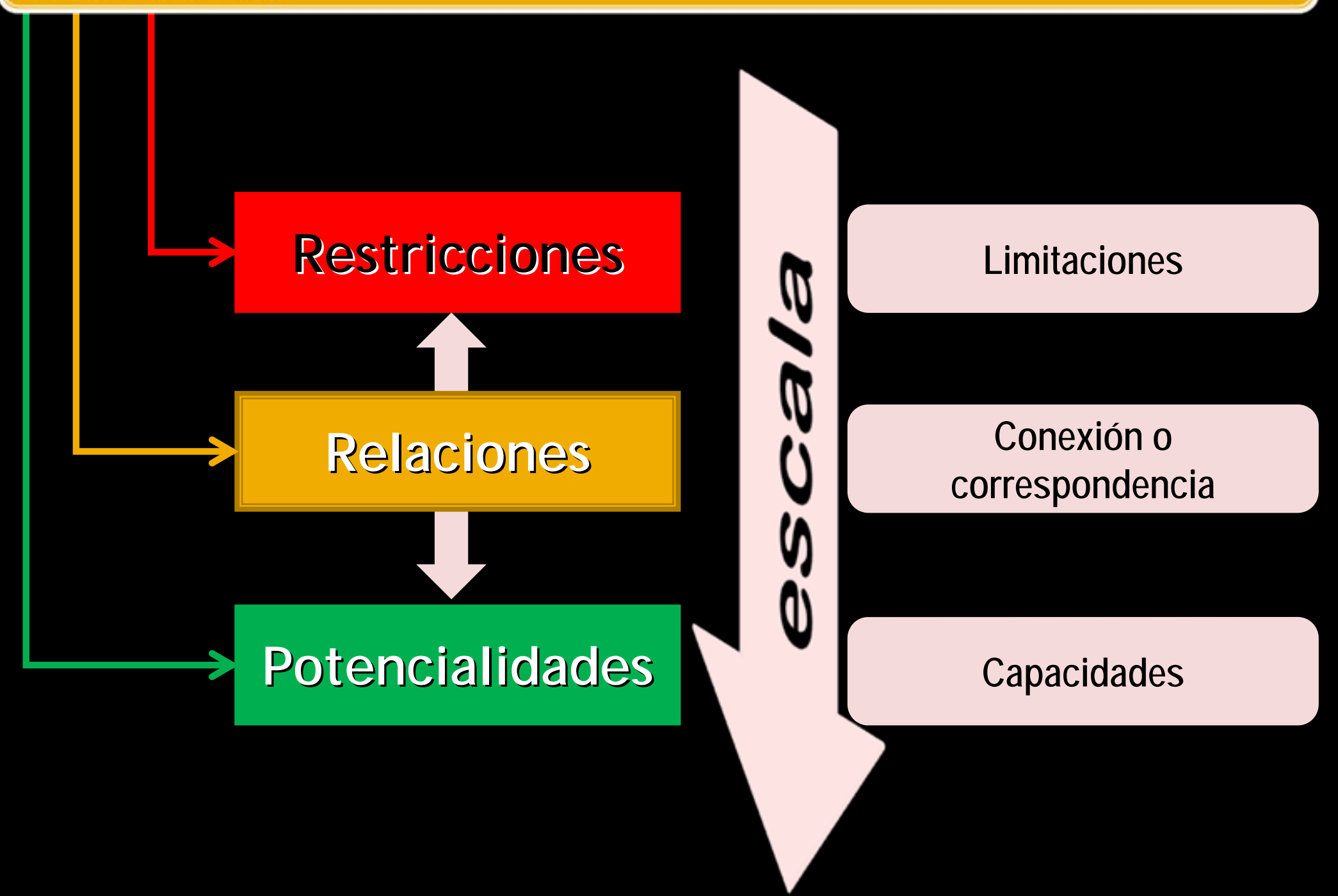

Publicado en formato digital: Ramirez, Mirta Liliana. Idea o tema cartográfico y fuentes de información: relaciones, restricciones y potencialidades. Resúmenes. Revista

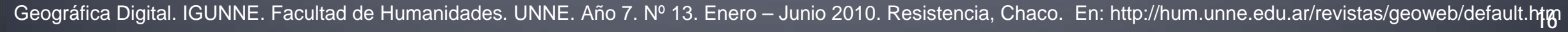




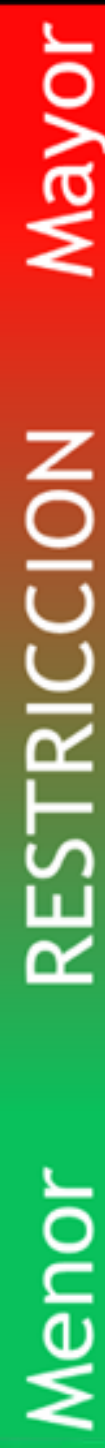

\section{FUENTES DE INFORMACJON: MAPA BASE}

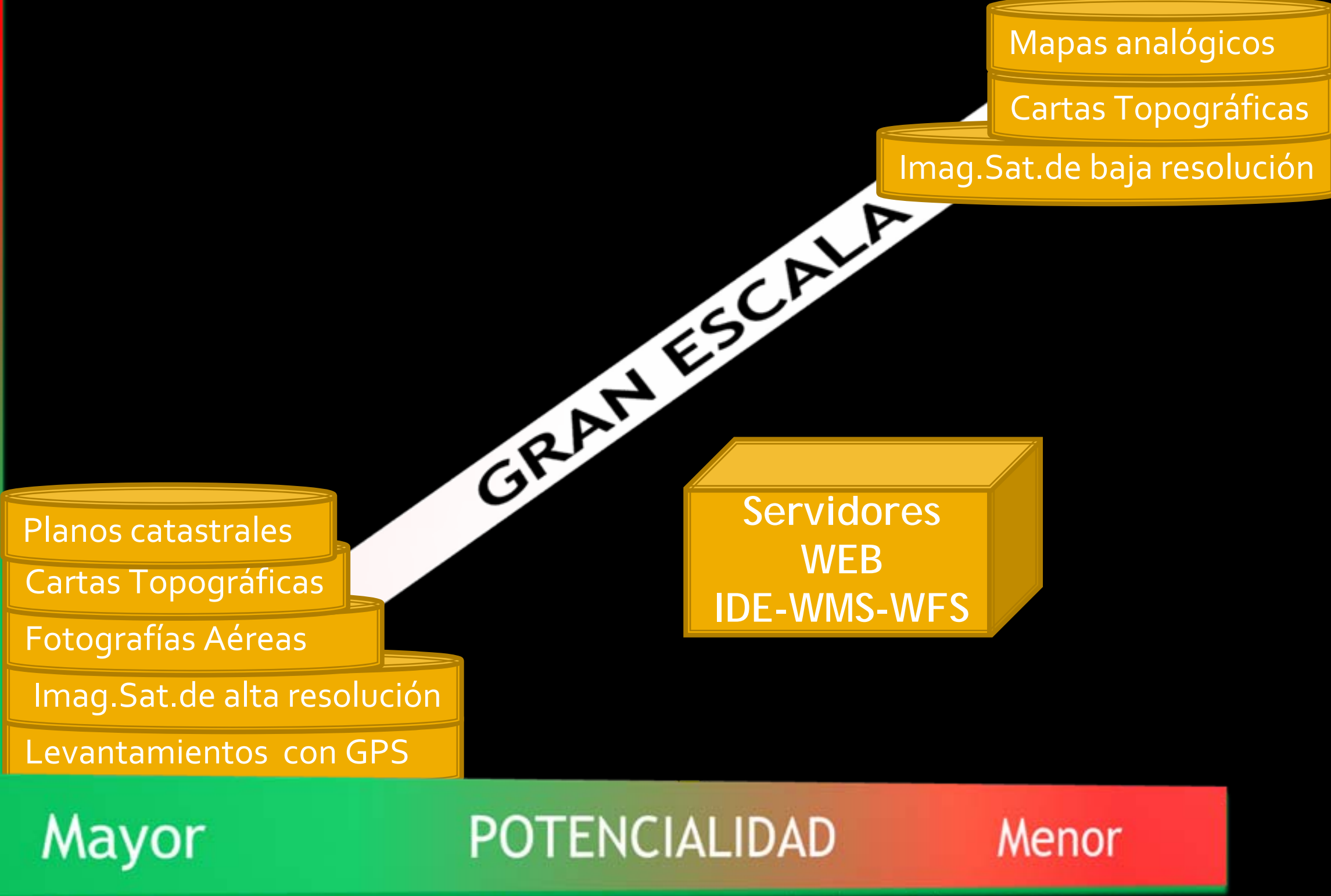

Publicado en formato digital: Ramirez, Mirta Liliana. Idea o tema cartográfico y fuentes de información: relaciones, restricciones y potencialidades. Resúmenes. Revista Geográfica Digital. IGUNNE. Facultad de Humanidades. UNNE. Año 7. № 13. Enero - Junio 2010. Resistencia, Chaco. En: http://hum.unne.edu.ar/revistas/geoweb/default.hł甲 


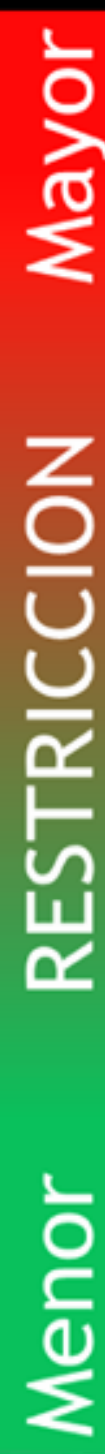

\section{FUENTES DE INFORMACION: MAPA BASE}

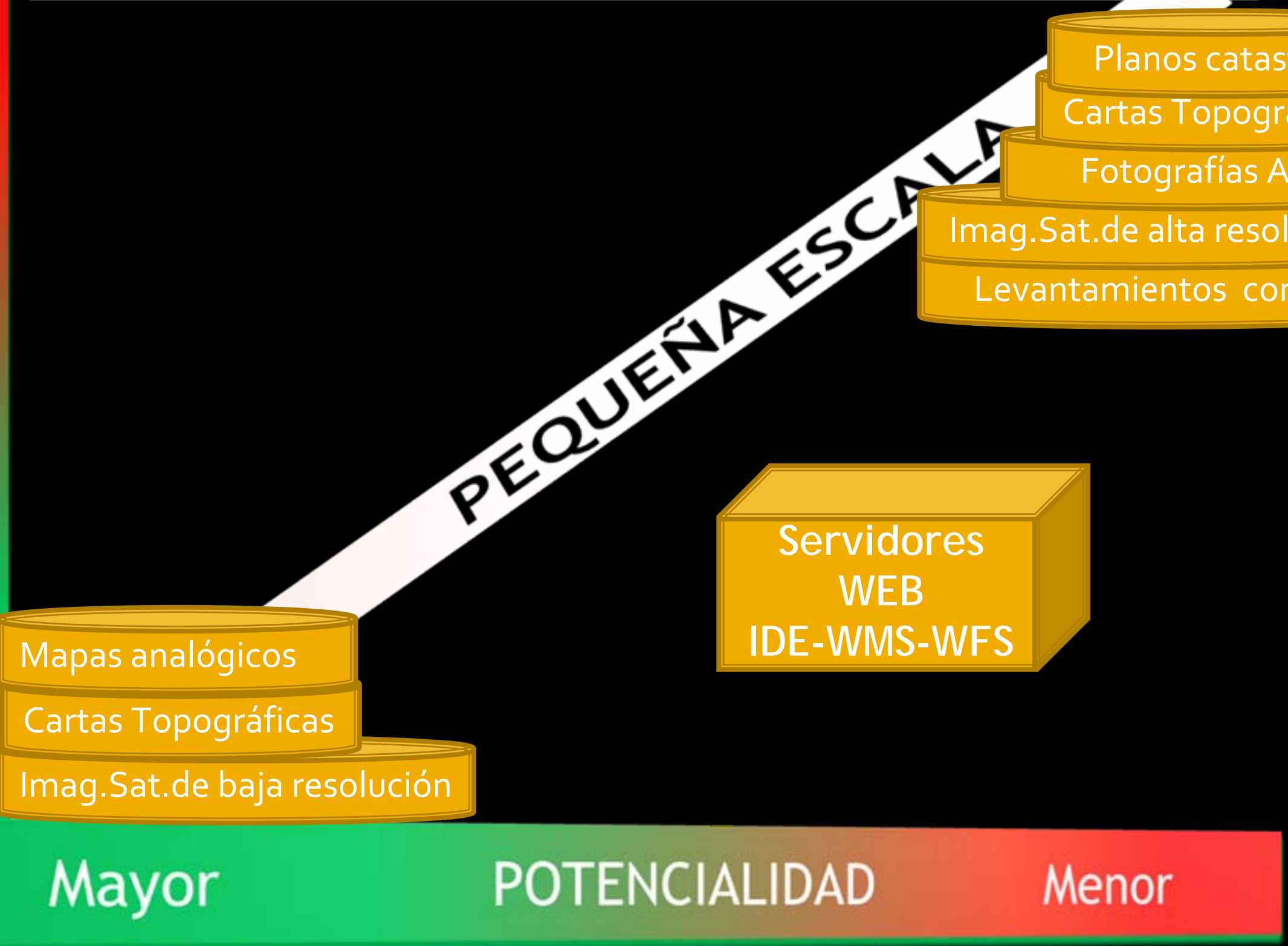

Publicado en formato digital: Ramirez, Mirta Liliana. Idea o tema cartográfico y fuentes de información: relaciones, restricciones y potencialidades. Resúmenes. Revista Geográfica Digital. IGUNNE. Facultad de Humanidades. UNNE. Año 7. № 13. Enero - Junio 2010. Resistencia, Chaco. En: http://hum.unne.edu.ar/revistas/geoweb/default.hłı 


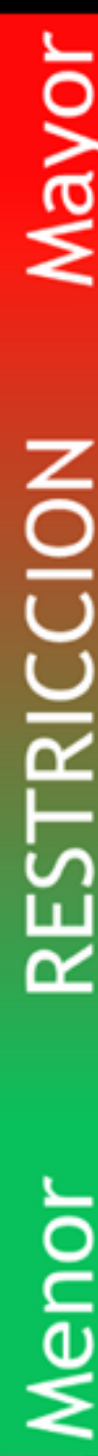

\section{FUENTES DE INFORMACION: INFORMACIONTEMATICA}

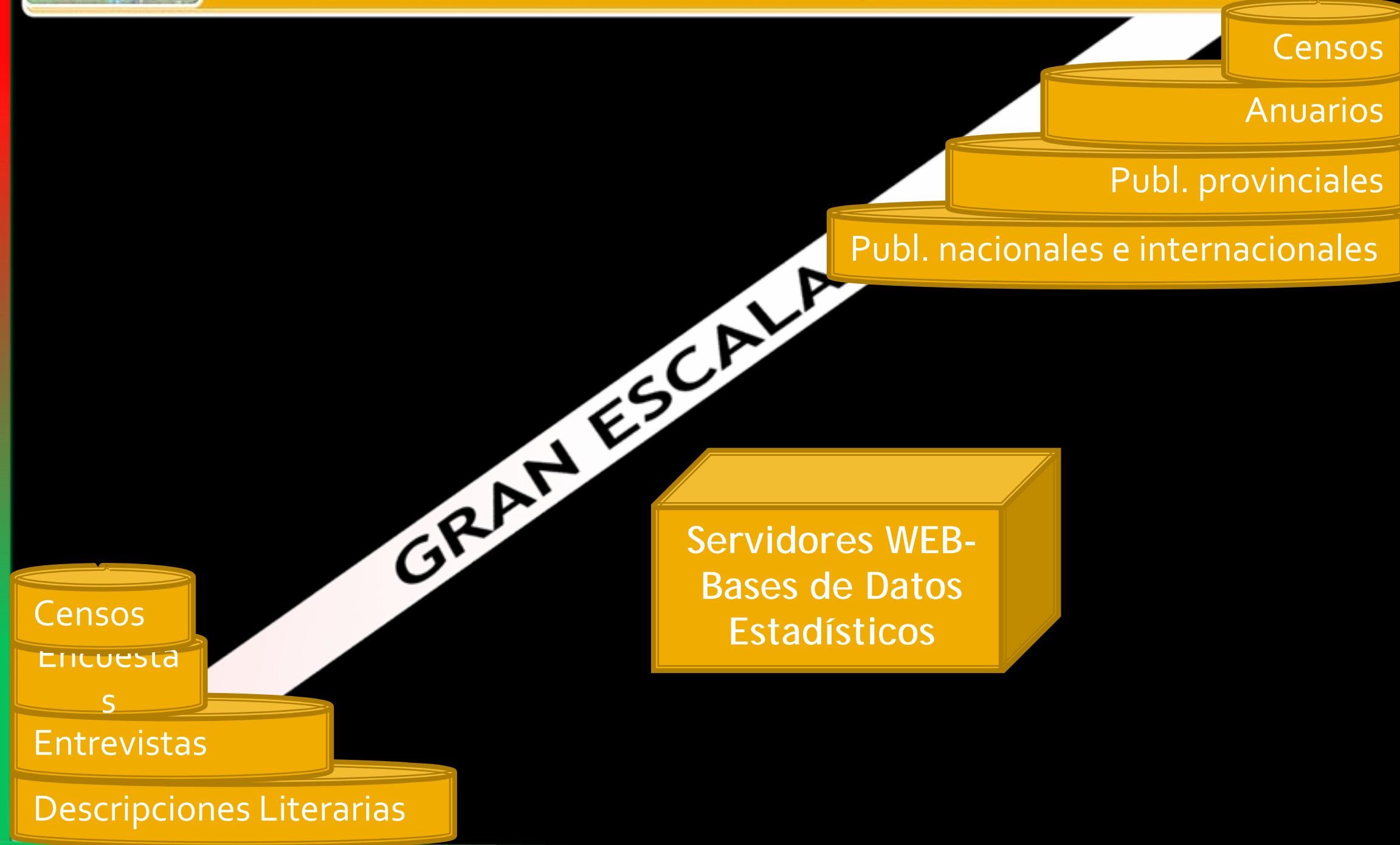

\section{Mayor}

\section{POTENCIALIDAD}

\section{Menor}

Publicado en formato digital: Ramirez, Mirta Liliana. Idea o tema cartográfico y fuentes de información: relaciones, restricciones y potencialidades. Resúmenes. Revista Geográfica Digital. IGUNNE. Facultad de Humanidades. UNNE. Año 7. № 13. Enero - Junio 2010. Resistencia, Chaco. En: http://hum.unne.edu.ar/revistas/geoweb/default.hłø 


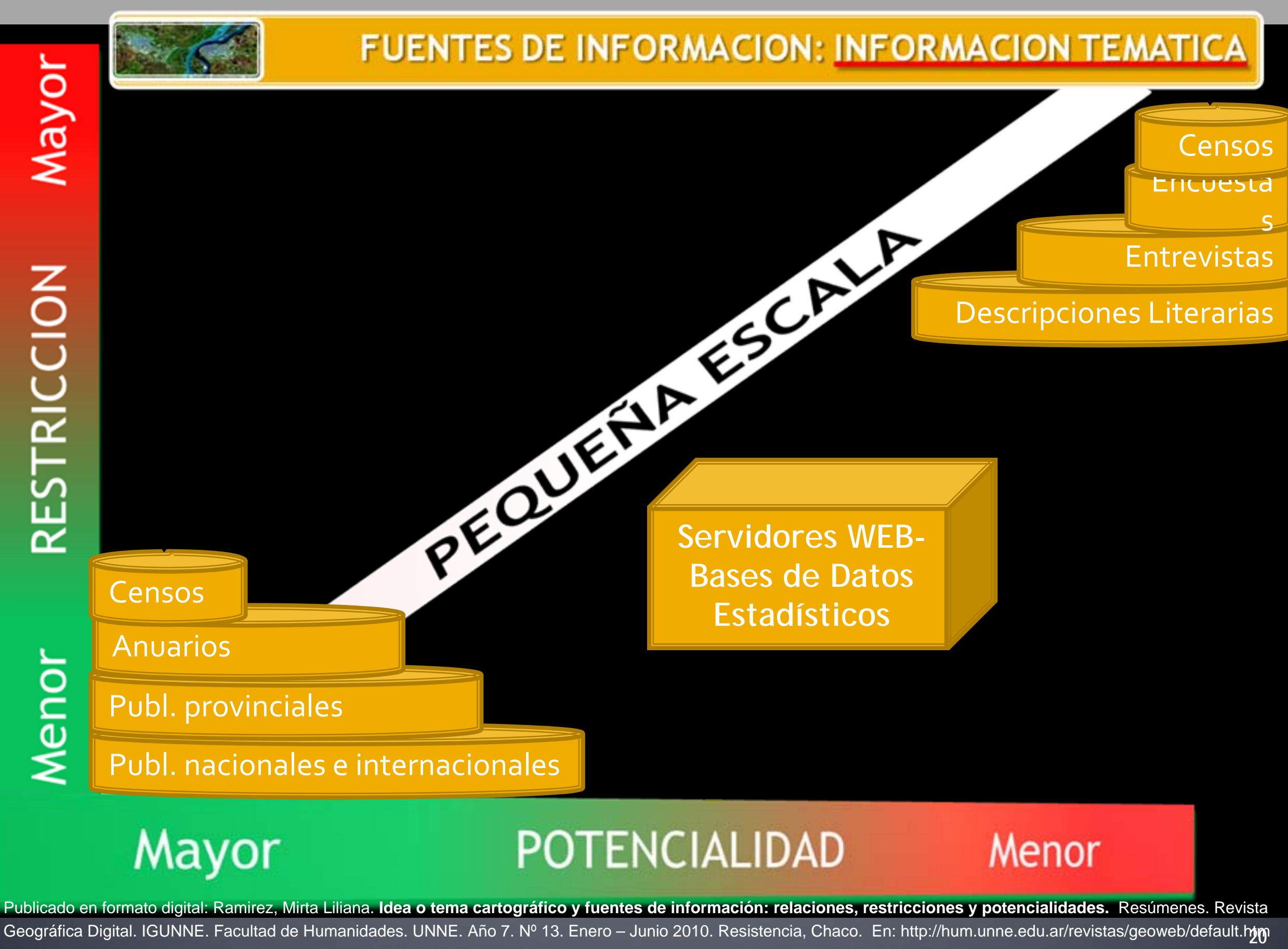




\section{A MODO DE CONCLUSION}

"desde finales de la Segunda Guerra Mundial, las actividades cartagráficas han alcanzado un gran desarrollo gracias a un progreso techológico evidente (n. )

No obstante (..) se están haciendo llamadas de atiención debido a la contradicción entre la aplicación de los métodos infiormáticos a la cartografía temálica y el desconocimiento de los principios de representación grálica y del lenguaje cartográlico (...)

Creemos que el cabal conocimiento científico del TIEMA A ABORDAR que deriva en la IDEA CARTOCRÁAFICA y en los aspectos que subyacen a ella -especificación de los objetivos, elección del mapa base y de la escala y el análisis de las fuentes de información-, constituyen una etapa de importancia extrema a la que no siempre se le otorga la relevancia y el tiempo que merece. 


\section{BIBLIOGRAFIA EMPLEADA}

-BERTIN, JACQUES (1973), Semiologie graphique. Les diagrammes, les réseaux, les cartes. Mouton - Gauthier Villars, París.

•BERTIN, JACQUES (1979). "Un test de base gráfica". En: Memoria sobre el I Seminario Sudamericano sobre Cartografía Temática. 13 al 17 de noviembre de 1978. Buenos Aires, Argentina.

-BOZZANO, HORACIO (1979). Introducción al proceso cartográfico. En: VIII Congreso Nacional de Cartografía. Junio de 1991, Santa Fe. Argentina.

-GARCIA-ABAD ALONSO, JUAN JAVIER (2002). La cartografía: nociones teóricas básicas. Curso: Cartografía Ambiental. Universidad de Alcalá. España.

-JOLY, FERNAND (1982). La Cartografía. Editorial Ariel. Barcelona, España 313 páginas.

-MIRANDA GUERRERO, R. y SANCHO COMÍNS, J. (2001). De la fundamentación teórica a la lectura científicotécnica del mensaje cartográfico. En: Revista Espacio, Tiempo y Forma. Serie IV, Geografía, t.14, pp. 11-36.

-MULLER, JEAN (1979). "Procesos para la confección de un mapa temático". En: Memoria sobre el I Seminario Sudamericano sobre Cartografía Temática. 13 al 17 de noviembre de 1978. Buenos Aires, Argentina.

- NUÑEZ DE LAS CUEVAS, RODOLFO (1991). Situación actual de la técnicas cartográficas en la producción de cartografía temática. Disponible en www. elagrimensor.net (febrero 2010).

-ROBINSON ARTHUR; SALE, RANDALL; MORRISON, JOEL Y MUEHRCKE, PHILLIP (1987). Elementos de Cartografía. Ediciones Omega. Barcelona, España. 543 páginas.

- Universidad Politécnica de Madrid (2003). Introducción a la cartografía temática y procesamiento de datos. Disponible en www.elagrimensor.net (febrero 2010).

- Universidad Politécnica de Madrid (2003). Introducción al diseño cartográfico. Disponible en www.elagrimensor.net (febrero de 2010). 